these virtues would be very popular, and that it would soon become one of the necessaries of life, without which no careful housekeeper would allow herself to be left.' It is further pointed out that, as the tree is abundant, and the expense of collecting the leayes would probably be very small, it would be quite worth while to procure a quantity either of the leaves or the juice from the West Indies, and endeavour to obtain a suitable preparation therefrom. If the leaves are brought they might be packed fresh in barrels, which should be filled with salt water-not sea water ind in this way imported ; 'or the juice might be expressed from them and saturated with salt, or preserved with benzoic or salicylic acid, and sent over in any convenient vessels. Experience would prove if they would retain these properties when so treated.' These hints may be worth the consideration of some of our readers in countries where the Papaw is abundant."

Anglesey, Gosport, August 4

S. P. OlIVER

\section{The Pacific Salmon}

THE reviewer of the U.S. Fisheries' Commission Report, I875-6, in NATURE, vol. xix. p. 429 , pointedly refers with doubt to a statement that "so far as yet observed the adult fish of the Pacific salmon (Salmo quinnat) all die after spawning" quoted from a memorandum which I wrote on the subject for the information of the New Zealand Government.

In support of this I would refer to the evidence given in a previous volume of the same reports, I872-3, p. I9I and elsewhere. This phenomenon, remarkable though it be, is so entirely in accordance with my own observations made during two seasons spent on the upper waters of the Columbia river in I 859.60 , and with the opinions I heard expressed by Indians and trappers, that I thought I was justified in mentioning it as a peculiarity of importance.

It may interest your readers to learn that a million of salmon ova of this species have been imported to New Zealand, and that over 700,000 have been hatched and that some 40 rivers have been stocked with the young fish.

Through the great liberality of the American Government at the instance of Prof. Spencer Baird, this invaluable addition to the future food resources of the Colony, has been effected at the cost of only a few hundred pounds to the Colonial Government.

JAMES Hector

Colonial Museum of New Zealand, Wellington, May ro

\section{A New Spectroscope}

IN NAture, vol. xx. p. 256 , a description of $M$. Cornu's spectroscope for observation of the ultra-violet rays is given.

The lens of the collimator, and that of the observing telescope are said to be composed of a double convex lens of quartz achromatized by means of a plano-concave of Iceland spar, both cut parallel to the optical axis. His prisms are said to be of quartz.

Will you allow me to state that $I$ have used an exactly similar arrangement for the last three years, with the exception that the two prisms are of Iceland spar, which has higher dispersive power. The object glasses were ground and polished for me by Mr. Ahrens of the Liverpool Road. I named the plan about two years ago to my friend Prof. McLeod, and have found it very successful in working. WILlmaM H. STONE

I4, Dean's Yard, Westminster, S.W., August 4

\section{"The Rights of an Animal"}

I BELIEve that when a writer feels himself to have been entirely misrepresented by his reviewer, editorial fairness allows him, at least in such journals as admit correspondence, to set himself right with the reader. The reviewer of my "Rights of an Animal" in NATURE, vol. xx. p. 287, says that, when I claim for animals "the same abstract rights of life and personal liberty with man," I use an ambignous word which casts its shadow over the entire work and makes it unsatisfactory. I should have thought "same" clearly meant "identical." My reviewer says that this cannot be my meaning, because I allow animals to be killed for food and to be worked. He forgets that I have shown how the law of self-preservation overrules the rights both of animals and of men, that it warrants our checking breeding in animals, and that the animals which I allow to be killed or worked were only allowed to come into life for those purposes.

He says that I consider it "immoral to eat shrimps and lob- sters." I have indeed asked how we are to defend the killing of "fresh-or salt-water fish or crustaceans," but I have suggested an answer, and have merely added "is this plea sound ?" That I leave a question doubtful does not justify a reviewer in saying that I decide it in a particular way.

I will not follow him into an argument between a very sophis. tical "philosopher" and a very stupid lobster, wherein the former gains an inglorious victory; but, when he in his proper person reproduces, anent another question, one of the philosopher's arguments, and charges me with " the same inconsistency of principle"-because "if man has a moral right to slay a harmful animal in order to better his own condition, he must surely have a similar right to slay a harmless animal, if by so doing he can secure a similar end"-I must protest that "principle" and "self-interest" are not synonymous, and that a writer who can pen such a sentence is no more capable of reviewing an ethical essay than I of reviewing a book on diamagnetism.

Lastly, he has (even in transcribing my title-page) omitted all mention of my reprints from Lawrence's interesting and very scarce work, and has conveyed to the reader an impression that my book consists of only about 60 pp., an impression very damaging to the chance of the reader buying or even borrowing it.

London Institution

EDWARD B. NICHOLSON

\section{Intellect in Brutes}

Mr. Henslow's question (NATURE, vol. xix. p. 433) reminds me of the celebrated carp and bucket of water problem, put by King Charles the Second. He had better have put it thus"Did ever a person know a dog (or other animal) ring a bell to bring a servant, \&c." How can any one tell if an animal goes through any "process of reasoning," save by the results? What will Mr. Henslow say to the following, for which I can vouch, as can others now living? For my part, having watched animals since my childhood, I am fully convinced of their "powers of reasoning" to a certain extent.

Many years ago we lived in Cambridge, in Emmanuel House, at the back of Emmanuel College. The premises were partly. cut off from the road by a high wall; the body of the house stood back some little distance. A thigh trellis, dividing off the garden, ran from the entrance door to the wall, in which was another door, or gate. A portion of the house, a gable, faced the trellis. These particulars are necessary, as you will see.

We were, after some time of residence, extremely troubled by "run-away-rings," generally most prevalent at night, and in rainy, bad, or cold weather, which was a great annoyance to the servant girls, who had to cross the space between the house and the wall, to open the outer door in the latter, and were thus exposed to wet and cold.

The annoyance became so great that at length a cousin and myself, armed with wicked ash saplings, watched behind the trees on " Jesus' Piece," bent on administering a sound thrashing to the eneny, whoever he was, that disturbed our "domestic peace." Mirabile dictu! the rings continued, but no one pulled the bell handle! Being a very old house, they were now of course set down to ghosts! but not believing in those gentry, I was puzzled. Chance, however, revealed the originator of the scare. Being ill I was confined to the wing facing the trellis, and one miserable, blowing, wet day, gazing disconsolately out of the window, espied my favourite cat-a singularly intelligent animal, much petted-coming along the path, wet, draggle-tailed, and miserable.

Pussy marched up to the house-door, sniffed at it, pushed it, mewed, but finding it firmly shut, clambered up to the top of the trellis, some eight or ten feet from the ground, reached a paw over the edge, scratched till she found the bell-wire which ran along the upper rail from the wall to the house, caught hold of it, gave it a hearty pull, then jumped down, and waited demurely at the door. Out came the maid, in rushed Puss. The former, after gazing vaguely up and down the street, returned, muttering "blessings," no doubt, on the ghost, to be confronted by me in the hall.

" Well, Lydia, I have at last found out who rings the bell." "Lard, Master! ye harvent surely"-she was broad "Zamerzetsheer." "I have; come and see. Look out of the breakfast room window, but don't show yourself." Meanwhile, I went into the drawing room, where Mrs. Puss was busy drying herself before the fire. Catching her up, I popped her outside of the door, and ran round to my post of observation. 